студентів, так і викладачів до навчальної діяльності, поглибленння знань та підвищенню якості навчального процесу. Упровадження інноваційних технологій в освітньому просторі України з кожним роком посилюється і виходить на новий рівень. Найчастіше інноваційні ідеї пов'язані з розвитком комп'ютерно-технічної бази, відкриттям нових закономірностей психологічного розвитку людини тощо. Нині застосування поява нових методів викладання, роботи зі студентською молоддю за допомогою різних комп'ютерних програм, дистанційних курсів не $є$ чимось не звичайним. Студенти, молоді викладачі зазвичай звикають і швидко пристосовуються до інновацій у навчальному процесі, що, в свою чергу, сприяє взаємодії «студентвикладач», i навпаки - як у професійній, так і в міжособистісній площині. Тому освітній процес в Україні має численні перспективи в галузі інноватики, а українські дослідники не припиняють наукових розвідок з цієї галузі з метою піднести якість вітчизняної освіти на найвищий європейський щабель, відповідаючи передовим стандартам навчально-виховних критеріїв освіти.

\title{
Література
}

1. Абасов 3. А. Понятийно-терминологический апарат инновационной педагогической деятельности / 3. А. Абасов // Философия образования. - 2006. № 1 (15). - С. 56-62. 2. Алексюк А. М. Педагогіка вищої освіти України. Історія. Теорія // підручник [для студентів, аспірантів та молодих викладачів вищих навч. закладів] / А. М. Алексюк. - К. : Либідь, 1998. - 560 с. 3. Высоцкий С. И. Дидактическое основания конструирования процеса обучения / С. И. Высоцкий, В. В. Краевский // Новые иследования в педагогических науках. - М., 1986. Вып. 1 (47). 4. Глушман О. В. Системний аналіз поняття «технологія навчання у вузі»: матеріали міжнар. наук.-практ. конф. «Педагогічна технологія у сучасному

вузі». - Луцьк, 1995. - С. 34-38. 5. Дубасенюк О. А Інноваційні навчальні технології - основа модернізації університетської освіти / О. А. Дубасенюк // Освітні інноваційні технології у процесі викладання навчальних дисциплін: Зб. наук.-метод праць / за ред. О. А. Дубасенюк. - Житомир: Вид-во ЖДУ, 2004. - С. 3-14. 6. Козлова О. І. Основні стратегії педагогічного впливу при традиційному та інноваційному підходах до навчання / О. І. Козлова // Педагогічні інновації: ідеї, реалії, перспективи: [зб. наук. праць] / ред. кол. Л. І. Даниленко та ін. - К. : Логос, 2000. - С. 239-245. 7. Кремінь В. Г. Вища освіта в Україні і Болонський процес: [навч. посіб.]. - К. : Освіта, 2004. - 384 с. 8. Мазоха Д. С. Педагогіка: [навч. посіб.] / Д. С. Мазоха, Н. І. Опанасенко. - К. : Центр навчальної літератури, 2005. - 232 с. 9. Фіцула М. Педагогіка: [навч. посіб.] / М. Фіцула. - [2-ге вид., випр., доп.]. - К. : Академвидав, 2005. - 559 с. 10. Фурман А. В. Методологічний аналіз систем розливального навчання / А. В. Фурман // Педагогіка i психологія. - 1995. № 1. С. 22 -26. 11. Ягупов В. Педагогіка: [навч. посіб.] / В. Ягупов. - К. : Либідь, 2002. -559 c.

УДК $37.0: 354$

Олексій Крюков, Світлана Луценко

\section{ІННОВАЦІЙНА ОСВІТА ЯК ОДИН ІЗ ОСНОВНИХ РЕСУРСІВ МОДЕРНІЗАЦІЇ СУЧАСНОЇ ДЕРЖАВИ}

Крюков О. І., Луценко С. М. Інноваційна освіта як один із основних ресурсів модернізації сучасної держави.

У статті порушуються питання взаємозв'язку інноваційної освіти та розвитку держави, визначено принципи управління інноваційними освітніми процесами. 
Особлива увага приділяється інноваційному розвитку навчальних закладів. Авторами доведено, що саме інноваційний потенціал освіти стимулює розвиток суспільства та держави.

Ключові слова: інновація, інноваційна освіта, глобалізація, суспільство знань, відкрита педагогічна система.

Крюков А. И., Луценко С. М. Инновационное образование как один из основных ресурсов модернизации современного государства.

В статье поднимаются вопросы взаимосвязи инновационного образования и развития государства, определены принципы управления инновационными образовательными процессами. Особое внимание уделяется инновационному развитию учебных заведений. Авторами доказано, что именно инновационный потенциал образования стимулирует развитие общества и государства.

Ключевые слова: инновация, инновационное образование, глобализация, общество знаний, открытая педагогическая система.

Kryukov A. I, Lutsenko S. M. Innovation education as one of the main resources in modernization of the modern state.

In the article the issue of the relationship of innovative education and development of the state is highlidhted, the principles of innovative educational processes are defined. Special attention is paid to the development of innovative schools. The authors demonstrated that the innovative potential of education encourages the development of the society and the state.

Key words: innovation, innovation education, globalization, knowledge society, open educational system.

На початок XXI ст. науково-технічна революція зумовила швидкі процеси глобалізації. До світу високих технологій увійшли поняття «глобальна економіка», «глобальна екологія», «глобальна освіта». Побутують різні точки зору науковців на процес глобалізації, але його не можна зупинити, тому що він $є$ об'єктивно закономірним.

Людство, стурбоване своїм виживанням, все більше звертається до проблем освіти, іiі розвитку та вдосконалення, оскільки вже нині вирішується, яким буде нове століття - освіченим або неосвіченим, гуманним або агресивним.

За загальним визнанням, кінець XX- початок XXI сторіччя - це період «глобальних інновацій» у галузях культури, економіки, техніки, суспільного й індивідуального життя. Глобальні інноваційні процеси супроводжуються прискоренням розвитку всіх сторін суспільного життя, що загострює і поглиблює суперечності між темпами суспільного та індивідуального соціокультурного розвитку. Багато робіт науковців (О. Мармаза, Л. Даниленко, Л. Карамушка, М. Поташник, А. Пригожин та ін.), визначаючи особливу роль освіти у створенні цивілізованого громадянського суспільства, присвячені розв'язанню цієї проблеми.

Mema cmammi - визначити взаємозв'язок між інноваційним розвитком освіти й суспільства та довести, що саме інноваційний освітній розвиток стимулює модернізацію сучасної держави.

Інноваційна політика $\epsilon$ складником соціально-економічної політики. Вона повинна об'єднувати загальними завданнями науку, техніку, виробництво, освіту і повинна бути орієнтованою на використання інтелектуальних ресурсів, розвиток високотехнологічних виробництв. 
У зв'язку з гуманітаризацією освіти виникає питання про межі зміни стилю і про кордони педагогічного впливу, а також ступінь впливу сумісності стилів діяльності учасників педагогічного процесу на розвиток пізнавальної активності останнього. Під час розгляду порушених питань виокремлено два найважливіші завдання сучасної освіти:

- по-перше, максимізувати процес сприйняття матеріалу й забезпечити розвиток пізнавального стилю діяльності учнів;

- по-друге, допомогти вчителю знайти свій стиль педагогічної діяльності, найбільш відповідає його індивідуальним особливостям, i, що найбільш важливо, вміти варіювати їм залежно від особливостей стилів діяльності учнів.

Становлення відкритих педагогічних систем сприяє сприйняттю і народженню нових ідей, їх трансформації й саморозвитку. Щоб забезпечити умови динамічних змін, розвивальна педагогічна система має бути відкритою, активною зорієнтованою на інновації. Відкритість педагогічної системи відображає іiі здатність передавати вироблені ідеї, способи роботи, форми взаємодії в різні галузі життя і діяльності людей та допомагає засвоювати нові ідеї, методи, соціальні, психологічні та педагогічні технології, перебудовуючи i розвиваючи за рахунок цього свою структуру.

3 огляду на сучасні світові тенденці Украіною проголошено курс на інноваційний розвиток. Він відображений у Концепціях державної інноваційної політики України [3], науково-технологічного та інноваційного розвитку України [4]; Законах України «Про інноваційну діяльність» [1], «Про загальну середню освіту» [2]; Положеннях «Про порядок здійсненя інноваційноі освітньої діяльності»[8], «Про експериментальний загальноосвітній навчальний заклад» [9] та ін.

Термін «інновація» було введено у використання ще у 1930-ті роки у якості позначенні того, що виходило за межі звичайного, традиційного. Взагалі інновація протиставлялась традиційним формам мислення, дії та поведінки. У середині 1980-их років широкого розголосу отримали дослідження у галузі освітніх інновацій, почали реалізуватись міжнародні проекти з розролення цього кола проблем. Інновацією стає будь-яка нова ідея, новий метод чи новий проект, що навмисно вводиться до системи традиційної освіти. Формується концептуальна схема підходів до розуміння інноваційних процесів як у контексті традицій, так і в контексті соціального визнання інновацій у якості бази задля здійснення нововведень у державній системі освіти: традиція - інновація - інституція. Саме це дозволило виключити протипоставлення традицій інноваціям і перетворення інновацій на щось негативне стосовно традицій, 3 одного буку, а з іншого, - надало змогу перетворити інновації на соціальні цінності та норми, тобто в такі інституції, що формуються у процесі соціальних комунікацій між особистостями і поступово стають традиціями.

Особливе, політичне значення феномен освітньої інноваційності отримав у першій половині ХХст. для характеристики розвитку постіндустріальної формації. Уведення новацій до економіки інтенсифікує економічні основи всіх форм соціального виробництва та, і як наслідок, різко підвищить рівень та якість життя людей. Отже, інноваційна економіка, продуктом якої, а відповідно і товаром на світовому ринку, є знання, повинна сприяти створенню та поширенню освітніх інновацій. Розвинені держави (США, Японія, Велика Британія) прямо проголосила про перехід на нову фазу розвитку як в економіці, так і суспільній галузі, заснованій на знаннях [5].

Як свідчить світовий досвід, формування інноваційної системи неможливе без активної участі держави. Роль держави у становленні інноваційної освіти значно 
більше, ніж під час регулювання звичайної освітньої політики. Це повинне передбачати розроблення стратегії переходу до інноваційної моделі розвитку на основі використання методів наукового планування на всіх рівнях управління, підвищення рівня інноваційної культури і освіти. Регулювальна соціальна роль держави в сучасному суспільстві акумулює функції державних органів по регулюванню освітніх інновацій. Навіть та країна, яка не має достатніх матеріальних і фінансових ресурсів, може досягти високих темпів зростання й технологічного прориву за рахунок використання інтелектуального й освітнього потенціалу нації й «людського капіталу». Ці твердження вкрай актуальні для сучасної України.

Ураховуючи те, що освіта є досить самостійною формою суспільної практики, особливою соціальною структурою, що стосується всіх інших галузей життя, універсальним засобом трансляції інформації та досвіду суспільства, необхідно звернути особливу увагу на інноваційну освіту. Визначаючи інноваційну освіту як освіту, здатну до саморозвитку та таку, що створює умови для повноцінного розвитку всіх своїх учасників, можна констатувати, що інноваційна освіта - це розвиваюча та така, що розвивається освіта. Відповідно, має змінитись розуміння і бачення самої структури сфери освітньої галузі. Освітнє середовище розуміється як:

- освітня інституція, у якій звертається увага на соціокультурний зміст освіти;

- освітній процес, тобто самоорганізована система діяльності суб'єктів освіти;

- зміст спільно-розподільчої діяльності суб'єктів освіти.

При цьому основними механізмами забезпечення цілісності структури $є$ освітня політика, що реалізує функцію самовизначення освіти серед інших суспільних практик та управління освітою, що скріплює іiі як цілісну сферу. Орієнтири інноваційного розвитку освіти визначаються концептуальними та програмними документами держави $[1 ; 3 ; 8]$.

В Україні розпочалося становлення нової парадигми освіти, орієнтованої на входження нашої країни до світового освітнього простору, поглиблюються тенденції диференціації освіти. Швидко розвивається міжнародне співробітництво, покликане сприяти розширенню можливостей громадян України щодо отримання якісної освіти й ефективного використання свого фахового потенціалу. Реалізація принципу варіативності надає змогу педагогічним колективам навчальних закладів обирати і конструювати педагогічний процес за будь-якими моделями, зокрема й інноваційними - авторськими.

Цей процес супроводжується суттєвими позитивними змінами в педагогічній теорії та практиці:

- створенням різних варіантів змісту освіти, використанням можливості сучасної дидактики у підвищенні ефективності освітніх структур;

- здійсненням наукових розробок i практичним обгрунтуванням нових педагогічних ідей і технологій.

Успіх освітніх реформ вирішальною мірою залежить від того, наскільки вдасться збудити творчий потенціал педагогів, які нині працюють у системі освіти.

Сучасні тенденції, закони і закономірності, наукові підходи, принципи, зміст і технології, що визнаються пріоритетними в управлінні навчальним закладом в умовах здійснення інноваційної діяльності, $€$ теоретико-методологічними засадами менеджменту освітніх інновацій - науки про управління людськими і матеріальними ресурсами в закладі освіти на засадах інвестицій та інновацій, у результаті якого якісно покращуються основні показники їхньої діяльності.

Управління інноваційними освітніми процесами здійснюється за певними 
принципами:

1. Принцип організованих інноваційних змін стану системи освіти. Він орієнтує на необхідність свідомої діяльності під час переходу від одного стану системи освіти до іншого, більш досконалого. Його використання передбачає певну систему діяльності, що охоплює етап підготовки до змін стану системи освіти й етапу реалізації цих змін. Етап підготовки передбачає обгрунтування основної мети змін, визначення засобів і умов реалізації цієї мети. Найскладнішим є забезпечення новими посібниками, методичними розробками, підготовленими кадрами.

2. Принцип переходу від стихійних механізмів управління інноваційними процесами до свідомих. Реалізація принципу передбачає відпрацювання ефективного механізму свідомого управління змінами.

3. Принцип інформаційного, матеріально-технічного, кадрового забезпечення реалізації основних етапів інноваційних процесів в освіті. Принцип передбачає забезпечення на кожному етапі інноваційного процесу.

4. Принцип прогнозування зворотніх або незворотніх структурних змін в інноваційному соціально-педагогічному середовищі. Дія цього принципу скерована на недопущення стихійних незапланованих змін, які можуть навіть зруйнувати інноваційне середовище.

5. Принцип підсилення стійкості інноваційних процесів в освіті. Сенс принципу полягає в тому, що під час переходу від стихійних процесів до керованих повинна посилюватися стійкість інноваційних процесів, їх спроможність до самозахисту та самоадаптації.

6. Принцип прискорення розвитку інноваційних процесів у системі освіти. Дія цього принципу розкриває ефективність організації та механізми реалізації інноваційних процесів.

Наведені принципи перебувають у тісному взаємозв'язку та $є$ елементами комплексної системи управління інноваційними процесами.

Реалізуючи принципи інноваційності, керівник навчальною закладу спільно 3 учасниками навчально-виховного процесу вносить постійні зміни до його діяльності і тим самим покращує їі результати.

Вищезазначені сучасні тенденціі, закони й закономірності, принципи управління навчальним закладом в умовах здійснення інноваційної діяльності покладені автором (Л. Даниленко) в основу теорії інноваційного освітнього менеджменту [7].

Навчальний заклад, що працює у режимі інноваційного розвитку, корелюєсвої цілі 3 державною політикою у галузі освіти, потребами суспільства, економічними можливостями регіону тощо. Тобто керівник такого закладу стає провідником державної освітньої політики та у своїй управлінській діяльності він повинен вибудовувати «місток» між пріоритетами у розвитку державної освітньої політики та реальною освітньою практикою. Саме тому задля успішної роботи йому необхідно орієнтуватися в інноваційних орієнтирах освіти. Крім цього керівник навчального закладу повинен своєчасно ознайомити $з$ цією інформацією свій колектив, для чого керівнику необхідно вміти не тільки працювати 3 різними джерелами інформації, визначати головне, виокремлювати найсуттєвіше, але й бути комунікаційно компетентним керівником, якому довіряють підлеглі. Адже повідомити інформацію можна по-різному: через наказ, розпорядження, виступ, а можна вмотивувати педагогічний колектив, викликати зацікавленість до інформації, до бажання обговорити, внести пропозиції щодо нововведень у системі діяльності навчального закладу [6].

Отже, інноваційний стан освіти та перспективи іiі розвитку значною мірою 
залежать від політики держави у цій галузі. У багатьох країнах державна освітня політика визначає високий професійний і загальнокультурний рівень населення, $\epsilon$ важливою умовою соціально-економічного розвитку, збереження і підвищення конкурентоспроможності національної економіки на світових ринках, безпеки і соціальної стабільності. Управління інноваційною діяльністю у навчальному закладі має свою специфіку і забезпечується знаннями теоретичних основ менеджменту освітніх інновацій, уміннями керівників створювати умови задля здійснення системного психолого-педагогічного експерименту, досвідом керівників щодо сприйняття ними навчального закладу як відкритої соціально-педагогічної системи, яка не $є$ сталою і характеризується постійними змінами, а отже, $є$ ресурсом інноваційного розвитку та модернізації держави.

\section{Література}

1. Закон України «Про інноваційну діяльність» - [Електроний ресурс] - Режим доступу: http://zakon4.rada.gov.ua/laws/show/40-15 2. Закон України «Загальну середню освіту»- [Електроний ресурс] - Режим доступу: http://zakon4.rada.gov.ua/ laws/show/651-14 3. Концепція державної інноваційної політики України. - [Електроний pecypc] - Режим доступу: http://ipwi.com.ua/Derjavne_reguluvannya_ ekonomiki/Kontseptsiya_derzhavnoi innovatsiynoi_politiki.html 4. Концепція науковотехнологічного та інноваційного розвитку України. - [Електроний ресурс]-Режим доступу: http://zakon4.rada. gov.ua/laws/show/916-14 5. Крюков О. I. Інноваційна модель економіки як чинник ефективної державної політики / О. І. Крюков, С. М. Луценко // Формування ефективних механізмів господарювання в умовах сучасної економики : теорія і практика: тези доповідей II Міжнародної науковопрактичної конференції 22-23 листопада 2012 р. / за заг. ред. В. М. Огаренка, та ін. Запоріжжя : КПУ, 2012. - С. 343-345. 6. Мармаза О. I. Інноваційні підходи до управління навчальним закладом / О. І. Мармаза. - Х. : Видав гр. «Основа», 2004. 240 с. 7. Освітній менеджмент / за ред. Л. Даниленко, Л. Карамушки. - К. : Шкільний світ, 2003. - 400 с. 8. Положення «Про порядок здійснення інноваційної освітньої діяльності» (наказ МОН України № 522 від 17.11.2000) Освіта України. - 2001. № 6. - С. 1-4. 9. Положення «Про експериментальний загальноосвітній навчальний заклад» (Наказ МОН України № 114 від 20.01.2002). - К., 2002. - 8 с.

$$
\text { УДК: 378.091.64:[378.016:81' 243] }
$$

Марія Куи

\section{ДИДАКТИЧНІ ОСНОВИ ВИКОРИСТАННЯ ТЗН У НАВЧАННI ІНОЗЕМНИХ МОВ}

Куц М. О. Дидактичні основи використання ТЗН у навчанні іноземних мов.

У статті розкриваються шляхи використання технічних засобів навчання іноземних мов; розглядаються питання інтенсифікації навчального процесу під час застосування фонограм, відеограм, відеофонограм, дидактичної техніки у тому числі на базі сучасних мультимедійних систем; робиться висновок щодо доцільності комплексного використання ТЗН для створення штучного іншомовного середовища.

Ключові слова: технічні засоби навчання, іншомовне середовище, навчання іноземних мов, інтенсифікація навчального процесу.

Куц М. А. Дидактические основы использования ТСО в обучении иностранным языкам.

В статье раскрываются пути использования технических средств обучения 